\title{
TIME TO GO BACK TO FIRST PRINCIPLES: A CRITICAL ANALYSIS OF THE 2017 PROCUREMENT REGULATIONS REVEALS THEM TO BE SHORT OF THE LEGALITY-CUM- RATIONALITY MARK
}

\author{
Lauren Kohn
}

(2019) 6 APPLJ 1

\begin{abstract}
Tendering has become an increasingly messy, high-stakes business; a disconcerting fact given the essential role public procurement plays in ensuring the delivery of vital goods and services to the public (using public money). The new (2017) Procurement Regulations complicate matters through, in particular, their allowance of pre-qualification criteria based on preference. In this article, I analyse three key ways in which the new Regulations seek to go further in the name of empowerment at the expense of competitiveness and hence cost-effectiveness. I illustrate that while not all of these new tools fall short of the legal mark, the use of tender conditions based upon preference for the purposes of pre-qualification, is unlawful and irrational given the methodology under the empowering Procurement Act and the need to give effect to all the constitutional procurement principles in a balanced way. I consider some anticipated practical knock-on effects of this; namely a perverse increase in fronting practices and hence diminished substantive empowerment, and an increase in litigation for non-compliance with tender conditions. On the latter score, I provide a jurisprudential snapshot of our courts' varying approaches to this assessment, culminating in an analysis of the AllPay test which I caution should be applied correctly and consistently to reduce the increasing lack of predictability in the procurement arena. I conclude by making some suggestions for reform that would be congruent with our blueprint constitutional "1st principles" and perhaps alleviate some of the pressure on our resource-stretched courts.
\end{abstract}




\title{
TIME TO GO BACK TO FIRST PRINCIPLES: A CRITICAL ANALYSIS OF THE 2017 PROCUREMENT REGULATIONS REVEALS THEM TO BE SHORT OF THE LEGALITY-CUM- RATIONALITY MARK
}

\author{
Lauren Kohn*
}

\author{
B.Bus.Sci, LLB, LLM (UCT); PhD Candidate \& Fellow (Leiden University, the \\ Netherlands)
}
Senior Lecturer (Administrative \& Constitutional Law), Department of Public Law, UCT; Attorney of the High Court of South Africa; Founder of www.SALegalAdvice.co.za

\section{Introduction}

Public procurement is a vital tool through which to realise the "social justice" promise - and indeed, potential - of our Constitution. ${ }^{1}$ It may not have been expressly identified as a particular "Karl Klare-ian" attribute ${ }^{2}$ of the Constitution that renders our supreme law "transformative" (or post-liberal) in nature, but perhaps it should have been. ${ }^{3}$ As Penfold and Reyburn have noted, "[w]ith the coming into effect of the Interim Constitution, government procurement was elevated to the status of constitutional principle" and "the South African legal system is unusual in entrenching the principles

\footnotetext{
* This piece flows from the research I did for my presentation at the 2nd International Public Procurement Law Conference, hosted by APLU (November 2018), and develops (extensively and substantively) my contribution in Quinot \& Williams-Elegbe 2019. I wish to thank Prof Geo Quinot for encouraging me to publish this piece and for his valued mentorship. I would also like to thank my friend, colleague and fellow law-lover, Raisa Cachalia, for her comments on a draft of this article, as well as the anonymous reviewer for his/her insightful commentary on aspects of the paper.

${ }^{1}$ The Constitution of the Republic of South Africa, 1996. See the Preamble in which explicit reference is made to the undertaking to "[h]eal the divisions of the past and establish a society based on democratic values, social justice and fundamental human rights" (emphasis added).

2 Klare 1998: 150 identified several distinguishing attributes that make the Constitution "transformative" in nature. He described "transformative constitutionalism" as:

"an enterprise of inducing large-scale social change through nonviolent political processes grounded in law. I have in mind a transformation vast enough to be inadequately captured by the phrase 'reform,' but something short of or different from 'revolution' in any traditional sense of the word. In the background is an idea of a highly egalitarian, caring, multicultural community, governed through participatory, democratic processes in both the polity and large portions of what we now call the 'private sphere"

${ }^{3}$ Though its component, "preferential procurement" (while not all there is to it), could of course fall within the reach of the "substantive equality" guarantee as explained in the Klare-ian sense.
} 
of public procurement in the Constitution" 4 thereby rendering this collective of bestpractice prescripts ${ }^{5}$ a justiciable constitutional litmus test ${ }^{6}$ in terms of which to assess all public procurement. Our Constitution is perhaps even more "unusual" insofar as it expressly contemplates the use of "preferential" or "targeted" state procurement to "correct past imbalances and to uplift vulnerable groups in society" - an indubitably transformative ambition, and a significant and welcome one. As Bolton has remarked, "making express provision for the use of procurement as a policy tool in a country's constitution is not common practice". ${ }^{8}$

This allowance for "redress procurement" should not, however, undermine the mandatory "starting-point section 217(1) procurement principles" (of which, "equity" is, after all, but one). As the Constitutional Court recently noted in the case of Buffalo City, "[s]ection 217 of the Constitution lays down the threshold requirements for a valid procurement process as one which is 'fair, equitable, transparent, competitive and cost-effective'.'9 Thus, although these "procurement principles" do not constitute an explicitly enumerated right, ${ }^{10}$ they are binding when it comes to public procurement

\footnotetext{
${ }^{4}$ Penfold \& Reyburn 2008: 25.1 and fn 5. (Emphasis added).

${ }^{5}$ Section 217 of the Constitution reads as follows -

"217 Procurement
}

(1) When an organ of state in the national, provincial or local sphere of government, or any other institution identified in national legislation, contracts for goods or services, it must do so in accordance with a system which is fair, equitable, transparent, competitive and cost-effective.

(2) Subsection (1) does not prevent the organs of state or institutions referred to in that subsection from implementing a procurement policy providing for-

(a) categories of preference in the allocation of contracts; and

(b) the protection or advancement of persons, or categories of persons, disadvantaged by unfair discrimination.

(3) National legislation must prescribe a framework within which the policy referred to in subsection

(2) must be implemented.

[Sub-s. (3) substituted by s. 6 of the Constitution Seventh Amendment Act of 2001 (wef 26 April 2002).]"

${ }^{6}$ The notion of a "litmus test" is apt given that our courts have confirmed that the section 217 procurement prescripts constitute a check-list of "minimum requirements for a valid tender process and contracts entered into following an award of tender to a successful tenderer". See Millennium Waste Management (Pty) Ltd. $v$ Chairperson of the Tender Board: Limpopo Province 2008 (2) SA 481 (SCA) para 4 (emphasis added).

${ }^{7}$ Bolton 2007: 263.

${ }^{8} 263$.

${ }^{9}$ Buffalo City Metropolitan Municipality v Asla Construction (Pty) Limited 2019 (6) BCLR 661 (CC) para 89 (emphasis added).

${ }^{10}$ Note, however, that Lornavision (Pty) Ltd v South African Broadcasting Corporation SOC Limited (19502/17) [2017] ZAGPJHC 208 read section 217 of the Constitution in light of National Treasury Practice Note 6 of 2007/2008 (Practice Note 6) paragraph 2.1, to proceed from the premise that -

"section 217 of the Constitution stipulates how Government's supply chain management system should be managed and also confers a 'constitutional right on every potential supplier to offer goods and services to the public sector when needed'." (See para 102, emphasis added). 
and the instrumentality of this public function for human rights realisation - and hence meaningful transformation of the fabric of our society - cannot be gainsaid. If procurement processes are flawed, stultified, delayed, poorly administered and/or corrupt, the domino effect is such that various constitutional infractions may ensue: infrastructure development may grind to a halt and/or be of a poor quality; service delivery may quickly become non-delivery - one need think only of the (barely averted) crisis in the SASSA-social grants-saga ${ }^{11}$ - public funds may be funneled for corrupt ends rather than public-purpose ends and so inevitably it is the human rights project that suffers. ${ }^{12}$

The point is that while public procurement may have slipped into section 217 of our Constitution (in chapter 13, "Finance"), ${ }^{13}$ given its inevitable implications for socioeconomic development and the substantial dent it thus makes in a country's gross domestic product (GDP); ${ }^{14}$ the state's capacity to govern effectively and responsively; and the rule of law ${ }^{15}$ itself, it is perhaps time we explicitly acknowledge it as the

\footnotetext{
${ }^{11}$ See AllPay Consolidated Investment Holdings (Pty) Ltd v Chief Executive Officer of the South African Social Security Agency (No. 1) 2014 (1) SA 604 (CC) (AllPay Merits) and AllPay Consolidated Investment Holdings (Pty) Ltd $v$ Chief Executive Officer of the South African Social Security Agency (No. 2) 2014 (4) SA 179 (CC) (AllPay Remedy).

${ }^{12}$ See Democratic Alliance $v$ Public Protector; Council for the Advancement of the South African Constitution $v$ Public Protector [2019] ZAGPPHC 132 para 106, "corruption and abuses of power for self-gain inevitably impact on the realisation of the rights in the Bill of Rights", and further Glenister $v$ President of the Republic of South Africa [2013] ZACC 20, para 57.

${ }^{13}$ Section 217 of the Constitution.

${ }^{14}$ The World Bank notes that public procurement as a percentage of a country's GDP ranges between $15 \%-25 \%$ in developed and developing countries alike - a staggering statistic. See World Bank The World Bank Group and Public Procurement: An Independent Evaluation International Bank for Reconstruction and development / The World Bank (2014).

See also the National Treasury Public Sector Supply Chain Management Review, 2015 (The 2015 SCM Review) where at 3, Treasury notes the following -

"Public expenditure nevertheless continues on a large and necessary scale. In 2013/14, the South African public sector spent R500 billion on goods and services and on construction works. These supported and enabled the delivery of services to the country's residents. This is an enormous amount of money. Wisely and efficiently spent, it can be a great force for good. It can ensure that those in need receive services, that infrastructure such as roads and ports is built and maintained, that schools are well-equipped and that health services are widely available. It can also spread wealth to hard-working entrepreneurs who successfully tender for government contracts and, in doing so, create jobs. Even those not directly involved in the public sector supply chain can benefit, as suppliers to government source their supplies and materials from manufacturers, farmers and many others".

[Available at: http://www.treasury.gov.za/publications/other/SCMR\%20REPORT\%202015.pdf]

${ }^{15}$ Section 1 (c) of the Constitution entrenches the rule of law as a founding value of our constitutional order. It entails, amongst other things, the principle of legality which may be summarised as the foundational requirement that "the legislature and executive in every sphere are constrained by the principle that they may exercise no power and perform no function beyond that conferred upon them by law". See Fedsure Life Assurance Ltd v Greater Johannesburg Transitional Metropolitan Council 1999 (1) SA 374 para 58.

On the various aspirations of the rule of law more generally, Kohn 2016: 247.
} 
animating overarching human-rights matter that it is: ${ }^{16}$ a crucial adjunct to our cornerstone Bill of Rights, and a matter always to be considered in light of related constitutional rights and obligations. On this latter note, the section 217 procurement prescripts must be read with the section 33 right to "Just Administrative Action", ${ }^{17}$ as bolstered by Chapter 10 of the Constitution which sets out, amongst others, the "basic values and principles governing the public administration", and the section 237 imprimatur that "[a]ll constitutional obligations...be performed diligently and without delay". ${ }^{18}$ This intersection between the procurement prescripts and administrative justice cannot be avoided; as the Constitutional Court put it in Steenkamp, "[s]ection 217 of the Constitution is the source of the powers and functions of a government tender board.... These requirement[s] must be understood together with the constitutional precepts on administrative justice in section 33 and the basic values governing public administration in section 195(1)."19

Therefore, public procurement lies at the heart of a complex constitutional composite of rights and duties and is perhaps the quintessential example of administrative law in motion given that it is by now well accepted ${ }^{20}$ that a procurement process is "administrative action" as defined. ${ }^{21}$ To this end, it is subject to the requirements of lawfulness, reasonableness, procedural fairness and, where rights are adversely

\footnotetext{
${ }^{16}$ Note that while I argue here that public procurement is indubitably and inevitably a human-rights matter per $s e$, this is related to, but distinguishable from, contemporary acknowledgements of it as a policy tool aimed at targeting particular human rights agendas. Quinot has for example argued that, "the question about the inclusion of policy considerations in public procurement in order to explicitly and deliberately promote human rights norms and thereby development should not be seen as a debate about whether policy considerations should be included in procurement or not, but rather about the most appropriate design for the inclusion of such policy considerations in procurement". (See Williams-Elegbe \& Quinot 2018:17).

${ }^{17}$ Section 33 of the Constitution reads as follows -

"33 Just administrative action

(1) Everyone has the right to administrative action that is lawful, reasonable and procedurally fair.

(2) Everyone whose rights have been adversely affected by administrative action has the right to be given written reasons.

(3) National legislation must be enacted to give effect to these rights, and must-

(a) provide for the review of administrative action by a court or, where appropriate, an independent and impartial tribunal;

(b) impose a duty on the state to give effect to the rights in subsections (1) and (2); and

(c) promote an efficient administration."

${ }^{18}$ Section 237 of the Constitution, "Diligent performance of obligations".

${ }^{19}$ Steenkamp NO v Provincial Tender Board of the Eastern Cape 2007 (3) SA 121 (CC) para 33 (emphasis added).

20 Logbro Properties CC v Bedderson NO [2003] 1 All SA 424 (SCA) para 5.

${ }^{21}$ See section 1 of The Promotion of Administrative Justice Act 3 of 2000 (PAJA) for the definition of "administrative action".
} 
affected, the duty to give written reasons. ${ }^{22}$ The public administration is that part of government that implements the laws; that translates them into discrete, concrete actions that have an impact on "we, the people" in our daily lives. As Hoexter has remarked,

"The area of government with which administrative law is chiefly concerned, the administration, is responsible for the practical running of the country on a dayto-day basis, and the translation of high-sounding executive policies and legislative aspirations into quotidian reality. Everyone is affected daily by administrative intervention, not merely in an abstract or philosophical sense but as a matter of practical (and often painful) fact'. ${ }^{23}$

The words emphasised are indicative of the fact that this "responsibility" is no mean feat; and so, insofar as public procurement (and the service, goods, and infrastructure delivery pursuant thereto) is a vital, daily, and often very costly ${ }^{24}$ manifestation of the state in action, it is important that the relevant stakeholders (particularly government) take heed of the layered legislative principles here. After all, as our Constitutional Court so powerfully remarked in the case of Kirland, "[government] is the Constitution's primary agent. It must do right, and it must do it properly." ${ }^{25}$ With the much-awaited publication of the Public Procurement Bill on the horizon, ${ }^{26}$ and in the wake of the notorious $^{27}$ Constitutional Court judgment in Gijima ${ }^{28}$ - which, with its kid-gloves

\footnotetext{
22 See section 33 of the Constitution.

${ }^{23}$ Hoexter 2000: 491 (emphasis added).

${ }^{24}$ Deputy Public Protector, Adv Kevin Malunga has highlighted that in South Africa, the national budget for procurement "now exceeds R1 million and it therefore goes without saying that public procurement is in effect the lifeblood of much economic activity throughout Africa and indeed the globe". See Williams-Elegbe \& Quinot 2018: vii.

${ }_{25}$ MEC for Health, Eastern Cape and Another v Kirland Investments (Pty) Ltd 2014 (3) SA 481 (CC) para 82.

${ }^{26}$ See van Wyngaardt M "Public Procurement aligned to more stringent regulations as Bill goes to Cabinet" (2018), available at https://www.polity.org.za/article/public-procurement-aligned-to-more-stringentregulations-as-bill-goes-to-cabinet-2018-02-21.

${ }^{27}$ Note that an analysis of this significant judgment (and all its practical ramifications) is beyond the remit of this article. For a critical analysis of this case, see for example, De Beer 2018: 613 and Boonzaier 2018: 642.

${ }^{28}$ State Information Technology Agency SOC Limited v Gijima Holdings (Pty) Limited 2018 (2) SA 23 (CC). In this contentious judgment the CC held that when an organ of state seeks to review its own decision for want of compliance with the tenets of administrative justice, it must do so not via the purportedly primary gateway to review (i.e. the PAJA), but rather via the flexible principle of legality with its more lenient procedural requirements (such as the time-frame within which to institute proceedings for judicial review) On this latter note, see Kohn 2013: 810.
} 
approach to aspects ${ }^{29}$ of "state self-review", ${ }^{30}$ is likely to spiral the spate of tender litigation - it is perhaps timely to pause and take stock of what it means in this context to "do right" and "do it properly".

This requires a refresher on what the first principles of public procurement as espoused in our Constitution entail. Against this backdrop, I reflect upon the 2017 Preferential Procurement Regulations, ${ }^{31}$ in order to illustrate how government is veering off the legal mark in its attempts at reform in this area. While I acknowledge the vital role of procurement as a policy tool to effect tangible economic empowerment and hence social redress, I argue that the manner in which these Regulations seek to achieve this laudable end renders them questionable on legality-cum-rationality grounds. I elucidate three key ways in which the Regulations seek to effect a more extensive tipping of the "procurement-principle-scales" in favour of empowerment; and arguably at the expense of fairness, competitiveness and cost-effectiveness.

I note that, in particular, the 2017 Regulations' radical shift of focus in favour of equity through an allowance of pre-qualification criteria, which may essentially close off the playing field to non-B-BBEE entities, is a worrisome affront to the section $217(1)$ principles holistically and purposively considered. From a pure legality perspective this

\footnotetext{
${ }^{29}$ In illustrating this more lenient approach to procedural prerequisites when it comes to state self-review, Boonzaier 2018: 658 notes for example, that Gijima is a volte-face given the Court's earlier jurisprudence which "recognised in the past that fidelity to PAJA is a useful means of suppressing the state's opportunism. Kirland, and a slew of subsequent judgments, emphasised with moral clarity that the rule of law requires that the state be held, despite its manoeuvrings, to proper processes, including the forms and limits of PAJA."

Note in particular, that the PAJA (in section 7) prescribes a strict time-limit for the institution of review proceedings: "without unreasonable delay and not later than 180 days...", although this may, under section 9, in "exceptional circumstances" be condoned by a court. In comparison, the common law position retained under legality review gives far more latitude to a reviewing party to approach a competent court at a later stage (provided it meets that nebulous requirement of being within a "reasonable time"), which keeps the "review door" open longer and hence increases the likelihood of future litigation.

${ }^{30}$ Buffalo City para 38, "the terrain of 'self-review', where a body seeks to review its own decision". See further the minority judgment in this case from para 112, "[s]tate self-review is a novel, but burgeoning, species of judicial review" and para 112 -

"The reasoning this Court advanced in Gijima for choosing legality as the appropriate pathway for state institutions' self-review has not found universal favour. While its treatment of standing and delay has been the immediate target of this criticism, Gijima is also accused of aggravating the bifurcation or 'parallelism' in our administrative law between PAJA review as opposed to legality review. This has been a persisting source of academic concern. It may in due course become necessary to reconsider whether the legality review pathway chosen in Gijima withstands the test of time. Now is not that time".

${ }^{31}$ The Preferential Procurement Regulations, 2017, published in Government Notice No. R32 of 20 January 2017 (the 2017 Procurement Regulations). They took effect on 1 April 2017 in accordance with regulation 17, "[t]hese Regulations are called the Preferential Procurement Regulations, 2017 and take effect on 1 April 2017".
} 
kind of "double-dibs" in the name of redress is clearly ultra vires the empowering Procurement Act, ${ }^{32}$ and its underlying section 217 constitutional blueprint, which (rightly) does not contemplate the use of "equity" as a gate-keeping device at the expense of the other goals of public procurement. Furthermore, given that the application of mandatory empowerment tender conditions to pre-qualify may be defeatist of these other procurement precepts, the "means" employed by government here are irrational when considered in light of the animating overarching objects of public procurement. And, if perhaps more speculatively, with so much now hinging on B-BBEE, the Regulations may, in turn, have the undesirable and anomalous effect of increasing fronting practices, thereby hindering true substantive empowerment.

In addition, the emphasis that the 2017 Regulations place on the use of tender conditions - particularly for (exclusionary) pre-qualifying purposes - is likely to increase the (oft vexatious) recourse to our resource-stretched courts. ${ }^{33}$ This, in turn, leads to further stalemate in government service delivery and thus the stultification of "popular efforts to transform society". ${ }^{34}$ The law reports are replete with instances of both state and private parties seeking to vitiate an otherwise lawful and fair tender process for want of (typically formal rather than substantive) compliance with tender conditions, and I provide a snap-shot of this case law to clarify the proper test for assessing the legality (or otherwise) of non-compliance. The 2017 Regulations are bound to aggravate this unfortunate common practice, thereby rendering the South African administrative lawyer's dream of a truly integrated and effective system of administrative law all the more illusory. ${ }^{35}$

Urgent reform of the 2017 Regulations is thus called for, along with pre-emptive and careful calibration of the new Bill in a manner that does justice to all of the constitutional

\footnotetext{
32 The Preferential Procurement Policy Framework Act, 5 of 2000 (the Procurement Act or PPPFA).

33 Volmink 2014: 41, "the disqualification of bidders on grounds of non-responsiveness has generated a considerable amount of litigation in South Africa". With even more now riding on pre-qualification empowerment criteria, more players will be excluded on responsiveness grounds, thereby increasing the likelihood of litigation.

${ }^{34}$ Davis 1993: 24.

35 Hoexter 2000: 485ff,

"The reason is, doubtless, that South African administrative law has never had much to offer except judicial review. South Africans have never experienced an integrated system of administrative law in which judicial review is regarded as merely supplementary to the business of making good primary decisions, and in which other forms of control and reconsideration-such as administrative adjudicationare taken seriously."
} 
ingredients for a valid public procurement process. To this end, a balanced, lawful and rational means of enhancing preference should be legislated such that vital considerations such as price are not undermined. Provision for a fast-track court process to challenge tender awards via a specialised court structure (in the form of tender courts akin to the electoral courts) would also be a welcome innovation in this context.

\section{$2 \quad$ Reflection on first principles}

In essence, the central argument of this article is that the 2017 Procurement Regulations are ultra vires the Procurement Act and section 217 constitutional procurement essentialia. This is a strong assertion and hence requires proper justification. As always, the starting point must be the Constitution which, given its supremacy, requires constitutional congruence on the part of all law and conduct for validity purposes. ${ }^{36}$

\section{The Section 217 Constitutional Procurement Provision}

Section 217(1) prescribes a mandatory default position for all public procurement in that whenever "an organ of state in the national, provincial or local sphere of government, or any other institution identified in national legislation contracts for goods or services" this "must" be done in accordance with "a system which is fair, equitable, transparent, competitive and cost-effective". These are the animating constitutional procurement precepts, ${ }^{37}$ which are mirrored in various other key statutes, ${ }^{38}$ and it is noteworthy that they are not ranked and should not be applied in a mutually destructive manner (for example, equity should not be pitted against competitiveness in an eitheror fashion). They cannot be cherry-picked; nor should they be collapsed. ${ }^{39}$ Rather, they must simply be appreciated as a globular list of (ideally) mutually reinforcing mandatory principles which must "be taken as a whole" 40 and applied in a balanced

\footnotetext{
${ }^{36}$ Section 2, read with section 172(1)(a), of the Constitution.

${ }^{37}$ For a detailed analysis of what each of these principles entails, see Bolton 2007: $40-54$.

38 See, for example, the Public Finance Management Act 1 of 1999 at section 38(1)(a)(iii) and the Local Government: Municipal Finance Management Act 56 of 2003 at section 65(2)(i).

${ }^{39}$ Note that I differ here with Penfold \& Reyburn 2008: 25.3(b) who appear to collapse the overarching and variable notion of "fairness" with the distinguishable (albeit related) goal of "equity" (what they term "equitability"); the latter seems to me to be more about the substantive equality goal of equity rather than mere procedural fairness - an issue pertaining to process - as they seem to suggest.

${ }^{40}$ Penfold \& Reyburn 2008: 25.3(e).
} 
and contextual manner, ${ }^{41}$ and which can most "emphatically" 42 be achieved by way of a transparent public tender process. ${ }^{43}$

Subsection 217(1) of the Constitution speaks predominantly to the administrative-law goal of regulating or constraining the state: procurement must be done in a manner that gives effect to all of these principles. Subsection (2) on the other hand, provides an empowering gloss in the form of an exception to the default principle of "nondiscrimination" in the procurement space. It is couched in permissive terms and as a carve-out to the subsection (1) rule -

"[s]ubsection (1) does not prevent the organs of state or institutions...from implementing a procurement policy providing for - (a) categories of preference in the allocation of contracts; and (b) the protection or advancement of persons, or categories of persons, disadvantaged by unfair discrimination".

As the words emphasised make clear, "[s]ection 217(2) of the Constitution does not place organs of state under an obligation to implement a preferential procurement policy" but rather simply provides that they are "not 'prevented' from using procurement as a policy tool." 44 Employed in this manner, section 217(2) of our Constitution certainly reflects "the broader notion of equality in South Africa, i.e. a substantive conception of equality as provided for in section 9[2] of the Constitution", ${ }^{45}$ however, this provision must be read in its specific procurement context such that the other section $217(1)$ procurement principles do not fade into insignificance.

\footnotetext{
${ }^{41}$ Bolton 2006: 206 - 207, where the author rightly notes that, "[e]ven though the principle of equity, in particular, cannot be ignored when organs of state procure, the principle (of equity) is only one of the five principles. It must be balanced with the other principles and the weight afforded to it will be determined by the facts and circumstances of the particular case." (Emphasis added)

This balancing exercise suggests that while there may be instances where the principles are mutually reinforcing, ultimately the facts will determine the relative weight to be given to each one and hence, how the scales ought to be tipped in the balance.

42 Penfold \& Reyburn 2008: 25.3(a).

${ }^{43}$ In Eskom Holdings SOC Limited v McKinsey and Company Africa (Pty) Ltd [2019] ZAGPPHC 185, para 20 the court noted that, "[a]s is clear from the language of s 217(1), its purpose is to eliminate fraud and corruption in a public tender process and to secure goods and services, for the public good, at the best competitive price in the market" (emphasis added).

44 Bolton 2007: 264.

45 Bolton 2007: 264.
} 
The section 217(2) permissive gloss on the subsection (1) mandatory procurement prescripts can thus be contrasted with the general section 9 equality right guarantee ${ }^{46}$ under which the subsection (2) restitutionary measures provision is not a carve-out from the non-discrimination rule, but rather an animating positive component of our commitment to substantive equality: "[p]ositive measures are therefore not an exception to, or a derogation from, the notion of equality; rather they are 'integral to the reach of our equality protection' and thus a vital part of the framework of $s 9 . "{ }^{4}$ So, while preferential procurement may be a valid affirmative action mechanism through which to effect redress (with the Procurement Act being such a measure ${ }^{48}$ ) there are other significant (and constitutionally prescribed) considerations at play in the procurement context aside from this equity goal, which in turn necessitates a careful calibration of the manner in which these aims may legitimately be achieved something the 2017 Regulations fail to do.

This is where section $217(3)$ of the Constitution comes in. It provides for constitutionally mandated legislation to "prescribe a framework within which the policy referred to in subsection (2) must be implemented." As noted, this legislation is the PPPFA (or Procurement Act), ${ }^{49}$ which is to be replaced by the much-talked about, but as yet publicly unseen, ${ }^{50}$ Public Procurement Bill, and the policy it seeks to give effect

\footnotetext{
${ }^{46}$ Section 9 of the Constitution reads as follows -

"9 Equality
}

(1) Everyone is equal before the law and has the right to equal protection and benefit of the law.

(2) Equality includes the full and equal enjoyment of all rights and freedoms. To promote the achievement of equality, legislative and other measures designed to protect or advance persons, or categories of persons, disadvantaged by unfair discrimination may be taken.

(3) The state may not unfairly discriminate directly or indirectly against anyone on one or more grounds, including race, gender, sex, pregnancy, marital status, ethnic or social origin, colour, sexual orientation, age, disability, religion, conscience, belief, culture, language and birth.

(4) No person may unfairly discriminate directly or indirectly against anyone on one or more grounds in terms of subsection (3). National legislation must be enacted to prevent or prohibit unfair discrimination.

(5) Discrimination on one or more of the grounds listed in subsection (3) is unfair unless it is established that the discrimination is fair".

${ }^{47}$ Kohn \& Cachalia 2017: 158.

${ }^{48}$ Regarding the Procurement Act itself being such a valid restitutionary measure, see, generally, Kohn \& Cachalia 2017: 146 on the test for redress measures within the meaning of s 9(2) of the Constitution.

49 The Procurement Act.

${ }^{50}$ Note that the 2017 Regulations were apparently intended as an interim measure pending the promulgation of the Procurement Bill.

See National Treasury CFO Forum Induction of 2 March 2017: Preferential Procurement Regulations, 2017: https://oag.treasury.gov.za/Event\%20Documentation/20170302\%20CFO\%20Forum\%20-

\%20AFS\%20Training/20170302\%20- 
to is plainly that of "preferential procurement". At this juncture, and at the risk of stating the obvious, two key points bear emphasis.

First, public procurement is, by definition, procurement for the public - typically to ensure goods, service and/or infrastructure delivery - using public money, and generally tremendous sums of it. ${ }^{51}$ As the Constitutional Court highlighted in AllPay Merits, ${ }^{52}$ "[a]ny contract that flows from the constitutional and statutory procurement framework is concluded not on the state entity's behalf, but on the public's behalf." In light of this, and the inevitably substantial financial in- and out-flows when it comes to public procurement, it must be done in manner that pays heed to all five of the constitutional procurement principles which, significantly, include competitiveness and cost-effectiveness. On this latter score it is perhaps worth reiterating that the procurement provision is, after all, included in the chapter on "finance".

Secondly, the Constitution explicitly contemplates the use of public procurement as an empowerment tool to right the wrongs of our past in order "to achieve economic transformation, create employment opportunities and reduce poverty". ${ }^{53}$ As noted, in this guise it is preferential, or "affirmative", ${ }^{54}$ procurement: a powerful mechanism to effect socio-economic change and, as I have suggested above, an arguably "transformative attribute" of our constitutional architecture. For this reason, our highest court has emphasised that, "economic redress for previously disadvantaged people also lies at the heart of our constitutional and legislative procurement framework" ${ }^{55}$

\footnotetext{
\%20Presentation\%20on\%20the\%20revised\%20Preferential\%20Regulations\%202017\%20National\%20Treasury\%20CFO\%20Forum.ppt (accessed 27 January 2020).

${ }^{51}$ See, for example, Trencon Construction (Pty) Limited $v$ Industrial Development Corporation of South Africa Limited 2015 (5) SA 245 (CC) para 1, where the court noted that, "in our society, tendering plays a vital role in the delivery of goods and services. Large sums of public money are poured into the process and government wields massive public power when choosing to award a tender. It is for this reason that the Constitution obliges organs of state to ensure a procurement process is fair, equitable, transparent, competitive and cost-effective." (Emphasis added).

On the important case of Trencon, see further Kohn 2015: 91 and Cachalia 2015:115.

${ }^{52}$ AllPay Merits para 46.

53 See the Gauteng Provincial Government: Supply Chain Management Policy Model para 6, available at: http://www.treasury.gpg.gov.za/Documents/Supplier\%20Chain\%20Management\%20Policy\%20Model.pdf.

${ }^{54}$ Bolton 2007: 263

${ }^{55}$ AllPay Merits para 47, emphasis added.
} 
In light of these two key points, the Procurement Act, as the framing legislation when it comes to public procurement, ${ }^{56}$ seeks to strike a suitable equilibrium between the aim of ensuring public money is appropriately spent (in simple terms: by getting the right man to do the right job for the right price, so to speak), and the aim of legitimate economic redress. These aims must therefore be pursued in a balanced way, for which reason the Procurement Act - albeit flawed and perhaps outdated in respects ${ }^{57}$ - sets out a carefully tailored methodology.

\section{The Methodology under the Procurement Act}

As its short title makes plain, the Procurement Act is the constitutionally ordained legislation aimed at "providing a framework for the implementation of the procurement policy contemplated in section 217(2) of the Constitution". It is a short and relatively straightforward statute that has been on the books for nearly two decades and, while perhaps needing a facelift, still presents some beauty in its simplicity. The "framework" or methodology it prescribes is essentially a dual-scale "preference point system" based on a fixed ratio of "price" to "specific goals", with the latter essentially being redress or "RDP" goals ${ }^{58}$ - in today's parlance, "broad-based black economic empowerment" (B-BBEE), ${ }^{59}$ or simply, "empowerment" goals.

\footnotetext{
${ }^{56}$ Note however, that this Act should nevertheless (and depending on the context) be considered alongside all relevant related legislation here, which Treasury has identified (in the 2015 SCM Review as the following:

"Public Finance Management Act 1 of 1999 (PFMA); Local Government: Municipal Finance Management Act 56 of 2003 (MFMA); Preferential Procurement Policy Framework Act 5 of 2000 (PPPFA); State Tender Board Act 86 of 1968 (STBA); Broad-based Black Economic Empowerment Act 53 of 2003 ('the Empowerment Act'); Prevention and Combating of Corrupt Activities Act 12 of 2004 (Corruption Act); Construction Industry Development Board Act 38 of 2000 (CIDBA); National Land Transport Act 5 of 2009; National Supplies Procurement Act 89 of 1970; State Information Technology Agency Act 88 of 1998; Financial Management of Parliament Act 10 of 2009; Road Traffic Management Corporation Act 20 of 1999; Armaments Corporation of South Africa, Limited Act 51 of 2003; Administrative Adjudication of Road Traffic Offences Act 46 of 1998; Nursing Act 33 of 2005; Public Audit Act 25 of 2004; Health Professions Act 56 of 1974; Housing Act 107 of 1997; Disaster Management Act 57 of 2002; Promotion of Access to Information Act 2 of 2000 (PAIA); Promotion of Administrative Justice Act 3 of 2000 (PAJA); Local Government: Municipal Systems Act 32 of 2000 (Systems Act). Regulations: PFMA SCM Treasury Regulations; MFMA SCM Regulations; Preferential Procurement Regulations and dti provisions for local procurement designations."

${ }^{57}$ Note that a discussion on this point is beyond the scope of this chapter and arguably moot given the pending promulgation of the new Public Procurement Bill; but see generally the 2015 SCM Review.

${ }^{58}$ Section 2(d) of the Procurement Act read with the Reconstruction and Development Programme, 1994 (which includes RDP goals such as the promotion of local businesses and SMMEs, rural enterprises and the like).

${ }^{59}$ See section 1 of the Empowerment Act, with which the regulatory framework governing procurement is now explicitly aligned. In this Act B-BBEE is defined to mean -

"the economic empowerment of all black people including women, workers, youth, people with disabilities and people living in rural areas through diverse but integrated socio-economic strategies
} 
Section 2 of the Act sets out this framework and couches it in mandatory terms. For present purposes, the following subsections bear reference:

\section{"2 Framework for implementation of preferential procurement policy}

(1) An organ of state must determine its preferential procurement policy and implement it within the following framework:

(a) A preference point system must be followed;

(b) (i) for contracts with a Rand value above a prescribed amount a maximum of 10 points may be allocated for specific goals as contemplated in paragraph (d) provided that the lowest acceptable tender scores 90 points for price;

(ii) for contracts with a Rand value equal to or below a prescribed amount a maximum of 20 points may be allocated for specific goals as contemplated in paragraph (d) provided that the lowest acceptable tender scores 80 points for price;

(d) the specific goals may include -

(i) contracting with persons, or categories of persons, historically disadvantaged by unfair discrimination on the basis of race, gender or disability;

that include, but are not limited to: increasing the number of black people that manage, own and control enterprises and productive assets; facilitating ownership and management of enterprises and productive assets by communities, workers, cooperatives and other collective enterprises; human resource and skills development; achieving equitable representation in all occupational categories and levels in the workforce; preferential procurement; and investment in enterprises that are owned or managed by black people". 
(ii) implementing the programmes of the Reconstruction and Development Programme as published in Government Gazette 16085 dated 23 November 1994...". 60

Importantly, under the Act, these redress goals may be utilised for the purposes of awarding preference points (i.e. for tender-scoring), but the PPPFA does not contemplate their use for pre-qualification purposes - certainly not explicitly, nor on a purposive implied reading of the Act's provisions. It is also noteworthy that the Rand value of the contract is determinative of the preference point scale to be used; either the "90/10" or " $80 / 20$ " scale. Money, after all, matters and as highlighted above, if it is not spent wisely (and indeed, properly) in this context, it is the human rights project that ultimately suffers.

Thus, for contracts above the threshold prescribed value, price is weighted more heavily (up to 90 points) than preference (up to 10 points); whereas for those below this monetary mark, the $80 / 20$ scale allows greater scope for redress goals (up to 20 points). The legislative logic is clear: the bigger (and hence more costly) the project, the greater the need to ensure public money is spent cost-effectively, and costeffectiveness is necessarily enhanced through increased competition. As the court noted in Joburg Market, "price is a central issue in the procurement process... It is... in the public interest to ensure that goods and services are secured for the best and lowest price possible." ${ }^{\prime 1}$ The 2017 Regulations, however, deviate from this focus and thereby upset the balance between price and preference in a manner that is beyond the scope of (or ultra vires) the empowering Act, read with its underpinning constitutional principles, and is thus unlawful. ${ }^{62}$ In addition, while government is of course rightly empowered to prioritise equity, doing so in a manner which renders the other procurement principles irrelevant - or worse still: nugatory - is irrational given

\footnotetext{
${ }^{60}$ Section 2(1)(a) - (b) of The Procurement Act, (emphasis added).

${ }^{61}$ Joburg Market SOC Ltd v Aurecon South Africa (Pty) Limited [2017] ZAGPJHC 145, (emphasis added).

62 This point is rendered glaringly obvious on a simple juxtaposition of the 2017 Regulations with their 2011 precursor, the Preferential Procurement Regulations, 2011, published in Government Notice No. R502 of 8 June 2011.

See Kohn, L "State procurement: The changing face of Public Procurement in SA", available at, http://www.caveatlegal.com/state-procurement-the-changing-face-of-public-procurement-insa/?fbclid=IwAR3mr4W3b3nRnQG_OhRGrjd2ADj7GPdo99fCSxJQd2hrGDU_ooQEhoFmlzg.
} 
the umbrella public procurement objective articulated in section 217(1) of the Constitution.

\section{Three key ways in which the 2017 Regulations tip the scales}

When considered alongside their 2011 counterparts, ${ }^{63}$ the "new" Procurement Regulations go much further in the name of empowerment. As elucidated above, overall this is a laudable, necessary and indeed legitimate policy move which accords with our constitutional commitment to socio-economic justice and hence societal transformation. This was simply put in AllPay Merits, ${ }^{64}$ as follows, "[t]he transformation that our Constitution requires includes economic redress", ${ }^{65}$ and we know preferential procurement is a valid and fundamental means to achieve this "equity" goal. But: not at the cost of the other (equally important) essentialia of public procurement. National Treasury has itself acknowledged this vital point,

"there is the challenge of finding the best balance between the two major objectives of procurement...development and transformation. An effective SCM system must also have as an objective to ensure that goods and services are available at the best price, in the right quantities, at the right time and in the right place". ${ }^{66}$

Hence, "measures to promote preference and socio-economic transformation will be conditional" in that they "must be aligned to section 217(1) of the Constitution" and "[c]ost premiums must be kept to a minimum". ${ }^{67}$ Lest we forget about these prescribed parameters: they are, after all the blueprint first principles. The 2017 Regulations, however, catalyse a divergence from them. These Regulations tilt the scales heavily in favour of redress in at least three significant ways which, I must emphasise, are not all legally short of the mark.

\footnotetext{
63 The 2011 Procurement Regulations.

${ }^{64}$ AllPay Merits.

${ }^{65}$ AllPay Merits para 46, (emphasis added).

${ }^{66}$ The 2015 SCM Review at 5, (emphasis added).

${ }^{67}$ The 2015 SCM Review at 14.
} 


\section{A dramatic increase in the determinative threshold value for point scoring}

As noted at 2.2 above, the Procurement Act empowers the Minister of Finance by way of regulation, to determine a "prescribed amount" which essentially serves as the determinative dividing line for scoring tenders according to either the "90/10" or the "80/20" preference point systems. ${ }^{68}$ The higher the value of the tender, the more likely it is that the former scale will have to be employed with a resultantly heavier focus on price and in turn a lesser focus on preference in the equation. Conversely, cheaper contracts with lower stakes for the public purse and goods/ service delivery can in turn accommodate an enhanced focus on empowerment.

Under the 2011 Regulations, this threshold value was set at R1 million such that, "[t]he 80/20 preference point system for acquisition of services, works or goods up to a Rand value of R1 million" would need to be used, ${ }^{69}$ and for all those with a value above this amount, the $90 / 10$ scale would kick in with price counting for up to $90 \%$ of the points to be scored. ${ }^{70}$ In the procurement space, R1 million is certainly not a tremendous sum, with the result that under the previous regulations most tenders stood to be measured according to the $90 / 10$ scale with price being the palpably more pressing criterion.

Come April 2017 however, the new Regulations shifted this balance - and enormously so - by moving the threshold value ${ }^{71}$ up to R50 million: a significant jump from R1 million. ${ }^{72}$ Practically, this means that almost all contracts will now be adjudicated using the 80/20 split with a resultantly heavier weighting for preference (i.e. B-BBEE ${ }^{73}$ ). The

\footnotetext{
${ }^{68}$ Section 2(1) of the Procurement Act.

${ }^{69}$ Regulation 5 of the 2011 Procurement Regulations.

${ }^{70}$ Regulation 6 of the 2011 Procurement Regulations.

${ }^{71}$ Under section 1 of the 2017 Procurement Regulations, "Rand value" is defined to mean "the total estimated value of a contract in Rand, calculated at the time of the tender invitation."

${ }^{72}$ See regulation 6, "80/20 preference point system for acquisition of goods or services for Rand value equal to or above R30 000 and up to R50 million" and regulation 7, "90/10 preference point system for acquisition of goods or services with Rand value above R50 million" of the 2017 Procurement Regulations.

${ }_{73}^{73}$ Under the 2017 Procurement Regulations, salient definitions in section 1 include, amongst others -

"B-BBEE" which is defined to mean "broad-based black economic empowerment as defined in section 1 of the Broad-Based Black Economic Empowerment Act";

"EME" which means "an exempted micro enterprise in terms of a code of good practice on black economic empowerment issued in terms of section 9(1) of the Broad-Based Black Economic Empowerment Act"; and

"QSE" which means "a qualifying small business enterprise in terms of a code of good practice on black economic empowerment issued in terms of section 9(1) of the Broad-Based Black Economic Empowerment Act".
} 
use of this mechanism to shift the emphasis in favour of redress is, however, consistent with section 2(b) of the Procurement Act which deliberately (and rightly) affords the Minister a wide discretion to determine the benchmark figure. ${ }^{74}$ It is furthermore non-offensive to section 217(1) of the Constitution in that there is still room for all the procurement prescripts to play a role in tender assessment: equity here is not used as a bar to the other considerations.

\section{Compulsory subcontracting}

Regulation $9^{75}$ of the 2017 Procurement Regulations is entitled "Subcontracting as condition of tender" and it applies to contracts with a value "above R30 million" and where "feasible". If these prerequisites are deemed met, the tender "must" be advertised "with a specific tendering condition that the successful tenderer must subcontract a minimum of $30 \%$ of the value of the contract" to "designated groups" with majority black ownership essentially being the key consideration here.

A purposive interpretation of this subcontracting requirement, read in its legislative context, is that it is aimed solely at "the successful tenderer", and is thus applicable post-award and, as noted, only where "feasible". ${ }^{76}$ On this interpretation, regulation 9

\footnotetext{
${ }^{74}$ See section 2 of Procurement Act, read with section 5(1) which later provision states that "[t]he Minister may make regulations regarding any matter that may be necessary or expedient to prescribe in order to achieve the objects of this Act".

${ }^{75}$ See regulation 9 of the 2017 Procurement Regulations.

"9 Subcontracting as condition of tender

(1) If feasible to subcontract for a contract above R30 million, an organ of state must apply subcontracting to advance designated groups.

(2) If an organ of state applies subcontracting as contemplated in subregulation (1), the organ of state must advertise the tender with a specific tendering condition that the successful tenderer must subcontract a minimum of $30 \%$ of the value of the contract to-
}

(a) an EME or QSE;

(b) an EME or QSE which is at least $51 \%$ owned by black people;

(c) an EME or QSE which is at least $51 \%$ owned by black people who are youth;

(d) an EME or QSE which is at least $51 \%$ owned by black people who are women;

(e) an EME or QSE which is at least $51 \%$ owned by black people with disabilities;

(f) an EME or QSE which is $51 \%$ owned by black people living in rural or underdeveloped areas or townships;

(g) a cooperative which is at least $51 \%$ owned by black people;

(h) an EME or QSE which is at least $51 \%$ owned by black people who are military veterans; or

(i) more than one of the categories referred to in paragraphs (a) to (h).

(3) The organ of state must make available the list of all suppliers registered on a database approved by the National Treasury to provide the required goods or services in respect of the applicable designated groups mentioned in subregulation (2) from which the tenderer must select a supplier." (Emphasis added).

76 This interpretation is strengthened by the fact that there is no reference in subregulation $9(3)$ to noncompliant tenders being rendered "unacceptable" (i.e. non-responsive) as is the case under the "pre- 
cannot be read as requiring all competing tenderers to show upfront how they will meet the " $30 \%$ subcontracting to designated groups requirement" given that so-called "compulsory subcontracting" under this regulation is conditional upon the actual award of the tender. This view is supported by the fact that subregulation $9(3)$ requires the relevant organ of state to -

"make available the list of all suppliers registered on a database approved by the National Treasury to provide the required goods or services in respect of the applicable designated groups mentioned in subregulation 9(2) from which the tenderer must select a supplier". ${ }^{77}$

A "tendering condition" within the meaning of regulation 9 is thus a peremptory subcontracting requirement for the tenderer who ultimately wins the bid. This is a legitimate way to achieve empowerment goals for it serves not as a requirement to compete, but rather a mandatory contractual requirement following the award of the tender. It is therefore congruent with the Procurement Act and underlying constitutional procurement principles.

However, regulation 9 must be read with subregulation 4(1)(c) which empowers organs of state to make subcontracting to designated groups a criterion for prequalification, and thereby affords them a discretion to invite, exclude and adjudicate bids accordingly. This brings me to the nub of my concern and the tipping-point pursuant to which I believe the new Regulations upset the scoring methodology under the empowering Act and are thus an unlawful and irrational affront to the section 217(1) procurement principles purposively and holistically considered.

\section{Pre-qualification criteria for empowerment}

Under regulation 4, "pre-qualification criteria for preferential procurement", ${ }^{78}$ organs of state are afforded an extensive discretionary power to employ specific tendering

qualification" and "functionality" regulations [regulations 4 and 5 the respectively, of the 2017 Procurement Regulations].

77 The implicit suggestion in subregulation 9(3) of the 2017 Procurement Regulations being that once a tender is awarded, Treasury must supply that successful bidder with the relevant list such that suitable subcontractors can be selected.

78 Regulation 4 of the 2017 Procurement Regulations reads as follows -

"4 Pre-qualification criteria for preferential procurement 
conditions for the restriction of procurement to particular categories of bidders. ${ }^{79}$ In this sense, these criteria or conditions are employed in a "'binary' way: bidders either qualify or they do not". ${ }^{80}$ Broadly speaking, tenders may be restricted ${ }^{81}$ in this manner for:

- tenderers with a stipulated minimum B-BBEE status level;

- EMEs or QSEs as defined in the Empowerment Act; and/or

- tenderers sub-contracting at least $30 \%$ of the contract value to an EME or QSE; again essentially on the basis of black majority ownership of these enterprises.

Subregulation 4(2) definitively states that, "[a] tender that fails to meet any prequalifying criteria stipulated in the tender documents is an unacceptable tender"; 82 and to this extent, regulation 4 may serve as an absolute bar to compete for non-B-BBEEcompliant tenderers; even where such apparently "non-starter bidders" are able to

(1) If an organ of state decides to apply pre-qualifying criteria to advance certain designated groups, that organ of state must advertise the tender with a specific tendering condition that only one or more of the following tenderers may respond-

(a) a tenderer having a stipulated minimum B-BBEE status level of contributor;

(b) an EME or QSE;

(c) a tenderer subcontracting a minimum of $30 \%$ to-

(i) an EME or QSE which is at least $51 \%$ owned by black people;

(ii) an EME or QSE which is at least $51 \%$ owned by black people who are youth;

(iii) an EME or QSE which is at least $51 \%$ owned by black people who are women;

(iv) an EME or QSE which is at least $51 \%$ owned by black people with disabilities;

(v) an EME or QSE which is $51 \%$ owned by black people living in rural or underdeveloped areas or townships;

(vi) a cooperative which is at least $51 \%$ owned by black people;

(vii) an EME or QSE which is at least $51 \%$ owned by black people who are military veterans;

(viii) an EME or QSE.

(2) A tender that fails to meet any pre-qualifying criteria stipulated in the tender documents is an unacceptable tender."

${ }^{79}$ See the National Treasury's “Frequently asked Questions" Brochure regarding the 2017 Regulations. At no. 3, Treasury states that, "[r]egulation 4 empowers institutions to use prequalification criteria for preferential procurement; this ensures advancement of categories of persons or categories of enterprises in a specific tender. Enterprises must meet a prequalification criterion to be evaluated further. Only enterprises who meet the prequalification criteria are evaluated further."

See,http://www.nwpg.gov.za/treasury/procurement2/documents/Frequently\%20asked\%20Questions\%20and \%20Generic\%20\%20Answers\%20-\%20Preferential\%20Procurement\%20Regulations\%202017\%20-

\%20Version\%201\%201.pdf ("Treasury FAQ Brochure").

${ }^{80}$ Quinot 2014: 1113.

${ }^{81}$ Note that at no. 9 of the Treasury FAQ Brochure, Treasury claims that, "[t]he regulations do not provide for set-asides but make provision for prequalification on the basis of criteria provided for in regulation 4". It is not entirely clear to me how restricting procurement to a certain category of bidders is something different from setting-aside such tenders to this effect.

82 Subregulation 4(2) of the 2017 Procurement Regulations. 
provide top-quality service offerings at competitive rates. Employed in this way, prequalification preference criteria stand to undermine the other procurement principles - most obviously, competitiveness and cost-effectiveness, which tend to go hand in hand. ${ }^{83}$

A detailed analysis of the definitional scope and interplay of the procurement principles is beyond this article's remit. Suffice it to note that competition should be understood in simple commercial terms as, "rivalry in the market, striving for custom between those who have the same commodities to dispose of". ${ }^{84}$ To prevent players offering essentially the same commodities or services (and arguably at better rates and/or of better quality) from tendering through the use of a preference-based gatekeeping device, reduces "rivalry in the market" and, concomitantly, the likelihood of securing the most cost-effective solution. ${ }^{85}$ Bolton has remarked that in the government procurement space, "[t]here can...only be competition or rather genuine competition, if...all interested parties are afforded an opportunity to participate." ${ }^{86}$ The use of preference as a pre-qualification criterion is an affront to this principle and, in turn, an affront to the PPPFA and section 217(1) of the Constitution, insofar as it breaches that animating twinset of constitutional 101s: legality and rationality. ${ }^{87}$

Both legality, and its related but distinctive rationality requirement, ${ }^{88}$ (minimally conceived $^{89}$ ) are implicated by subregulation 4 insofar as it is beyond the scope of the

\footnotetext{
${ }^{83}$ Bolton 2007: 40, "the principle of competitiveness can, to a large extent, be said to be interconnected and interrelated with the principle of cost-effectiveness. Both principles concern the attainment of value for money and both signify that while an organ of state must, in terms of section 217(1) of the Constitution, also take account of principles of fairness, equity and transparency when contracting, it should obtain the best possible value for money as far as possible."

${ }^{84}$ The Oxford English Dictionary, available on-line at:

https://www.oed.com/view/Entry/37578?rskey=91Zk34\&result=1\&isAdvanced=false\#eid (accessed 28 January 2020).

${ }^{85}$ Note that there may however be instances in which the converse holds true; namely where a focus on costeffectiveness reduces competition. See Bolton 2007: 43 for an analysis of the permutations here.

${ }^{86}$ Bolton 2007: 43.

${ }^{87}$ See Kohn 2013: 810 on the development of the principle of legality-cum-rationality, and Fedsure regarding the "legality" requirement.

${ }^{88}$ The Constitutional Court itself has started to lump these (distinguishable but related) notions together. See for example, Maset/ha $v$ President of the Republic of South Africa 2008 (1) SA 566 (CC) paras 42 \& 77-78

${ }^{89}$ See Pharmaceutical Manufacturers Association of South Africa and Another: In re Ex Parte President of the Republic of South Africa 2000 (2) SA 674 (CC) from para 85-86 and para 90:

"It is a requirement of the rule of law that the exercise of public power by the executive and other functionaries should not be arbitrary. Decisions must be rationally related to the purpose for which the power was given, otherwise they are in effect arbitrary and inconsistent with this requirement...
} 
Procurement Act and constitutional procurement essentialia to employ equity in a manner that renders the other essentialia largely irrelevant - or at least underweighted - given the animating objectives of public procurement as explained above. ${ }^{90}$ In its least onerous guise, ${ }^{91}$ rationality demands a logical link between a (legitimate) governmental purpose and the means sought to achieve that purpose; otherwise what we are in effect faced with is arbitrary governance - a malady abhorrent to a true constitutional democracy. ${ }^{92}$ Applying this principle to the issue under consideration, to count empowerment twice such that due recognition of price is essentially excluded, cannot be a rational "means" given public procurement is in large part about the goal of ensuring quality well-priced offerings are secured in the public interest. ${ }^{93}$ But there is a further related problem pursuant to which the Regulations are wanting on pure legality grounds. Where a minimum B-BBEE status level is used as a peremptory prequalifying criterion within the meaning of regulation $4,{ }^{94}$ and then necessarily features again at "preference point allocation" stage, this ultimately allows for a kind of double counting which is clearly not contemplated under the empowering legislation, and is hence ultra vires. Quinot has noted that,

"[o]nce the pre-qualification has been applied in a given procurement, the bids that meet these pre-qualification criteria will be adjudicated in terms of the normal rules of adjudication; i.e. functionality assessment followed by price and preference comparison". ${ }^{95}$

So, let us say that an organ of state exercises its discretion to make a "minimum [level 1] B-BBEE status" ${ }^{\prime 96}$ a mandatory prequalifying tender condition: only enterprises with a scorecard to this effect can compete. Preference is the singular litmus test at this stage. But then, we move to point-allocation stage and again, preference features as it of course must in the normal course (the $90 / 10$ or $80 / 20$ scorecard applies; but likely

Rationality in this sense is a minimum threshold requirement applicable to the exercise of all public power by members of the executive and other functionaries. Action that fails to pass this threshold is inconsistent with the requirements of our Constitution, and therefore unlawful." (Emphasis added).

${ }^{90}$ See sections 1 and 2 above.

${ }^{91}$ See Kohn 2013: 824 and the cases analysed therein.

92 Electronic Media Network Limited Others v e.tv (Pty) Limited 2017 (9) BCLR 1108 (CC) para 5.

${ }^{93}$ See Minister of Social Development v Phoenix Cash \& Carry Pmb CC [2007] 3 All SA 115 (SCA) para 2, "the public interest is...best served by the selection of the tenderer who is best qualified by price".

${ }^{94}$ Within the meaning of subregulation 4(1)(a) of the 2017 Procurement Regulations.

${ }^{95}$ Quinot 2017: 1.1.3.

${ }^{96}$ As contemplated by subregulation 4(1)(a) of the 2017 Procurement Regulations. 
the latter given the dramatic increase in the threshold value). Thus, we have the Regulations permitting a kind of "double-dibs" in contravention of the Act, and seemingly at odds with Treasury's attempt to try "its level best within the confines of the Constitution and the PPPFA to formulate sufficiently empowering regulations". ${ }^{77}$

Double-counting, albeit on the distinguishable basis of functionality ${ }^{98}$ at the expense of price, was found to undermine the scoring system in the PPPFA in the case of Contour Technology. ${ }^{99}$ In this case, the municipality employed functionality as a threshold factor ${ }^{100}$ in considering the responsiveness of the various bids, but then apparently "faced with extreme difficulty in comparing the bid prices of Contour and Cigicell" decided simply to award them both a full 90 points for price and "once again had recourse to functionality"101 as a deciding point-scoring mechanism. The court lamented this unlawful allowance of a second bite of the cherry and the disregard for the need properly to apply the prescribed points-scoring mechanism under the Procurement Act. Tuchten J expressed dismay at the fact that, "the procedure and methodology prescribed by the PPPFA was simply not followed" in that there was a "revised functionality" assessment and price did not feature at all in the scoring. ${ }^{102}$

To summarise, and applying the Contour Technology reasoning by analogy, the 2017 Procurement Regulations' allowance of "double dipping" on the basis of preference is beyond the scope of the empowering Act insofar as it essentially permits equity to be weighted more heavily than the maximum $20 \%$ contemplated under section 2 of the PPPFA. This is because B-BBEE may count as a prerequisite simply to enter the game, and then it necessarily counts again at preference-point-scoring stage. This in turn amounts to a breach of the constitutional procurement principles holistically and purposively considered insofar as the Regulations will likely have the (unlawful and irrational) effect of rendering such tender processes less competitive and so potentially also less cost-effective. We should not forget these basic premises of public

\footnotetext{
${ }^{97}$ No.8 of Treasury FAQ Brochure.

${ }^{98}$ Functionality has always (and rightly) been considered the quintessential pre-qualification consideration. Under the new Regulations it is defined to mean, "the ability of a tenderer to provide goods or services in accordance with specifications as set out in the tender documents".

${ }_{99}$ Contour Technology (Pty) Limited v Chairperson of the Bid Adjudication Committee: Modimole Local Municipality [2017] ZAGPPHC 496.

100 para 9.

101 Para 18.

102 Para 16.
} 
procurement; as the court noted in Abet Inspection, ${ }^{103}$ where a tender process is such that there is "obvious" prejudice to "competitiveness and cost-effectiveness", the "objects of s $217(1)$ of the Constitution" will likely be "frustrated, rather than promoted".

\section{Further unintended consequences: the subversion of true substantive empowerment \& the spiralling of tender litigation}

\section{The 2017 Regulations' skewed emphasis on preference is likely to undermine genuine empowerment}

Enhanced efforts to further socio-economic empowerment goals (in our still largely untransformed South African landscape) are vital. However, as emphasised above, these efforts must remain within the remit of the empowering legislation and underpinning constitutional provisions in order to meet the "minimum threshold requirement" for all exercises of public power; namely legality and rationality. ${ }^{104}$ The rule of law, which is an animating value of our constitutional order, requires as much. ${ }^{105}$ The 2017 Regulations fail this threshold test for the reasons stated at 3 above: in seeking to further preferential procurement they go too far; particularly by permitting the use of redress criteria for (exclusionary) pre-qualification purposes, and to this extent they undermine the broader objectives of public procurement within our constitutional schema.

An additional (but related) rationality worry to flag, is that regulation 4 is likely to have the self-defeating unintended consequence of increasing fronting practices on the part of otherwise non-qualifying entities seeking to "enter the game". This will in turn subvert the overarching empowerment aim, rendering the "means" employed in the Regulations irrational. In AlIPay Merits, ${ }^{106}$ the Constitutional Court took great care in unpacking the germane aspects of the Empowerment Framework in the procurement context and highlighted that, as always, it is "[s]ubstantive empowerment, not mere formal compliance...[that] matters" and to this end, "[t]he Empowerment Act and regulations make it clear that broad and sustainable involvement by black people is

\footnotetext{
${ }^{103}$ ABET Inspection Engineering (Pty) Ltd v The Petroleum Oil and Gas Corporation of South Africa [2018] ZAWCHC 7 para 24.

${ }^{104}$ See Fedsure and Pharmaceutical Manufacturers.

${ }^{105}$ Section 1(c) of the Constitution.

${ }^{106}$ AllPay Merits.
} 
required, and that the development and transfer of the necessary skills are an integral part of such transformation". ${ }^{107}$ Fronting, ${ }^{108}$ also referred to as "window-dressing" or "tokenism", ${ }^{109}$ involves the fraudulent use of employment credentials as a "charade"110 and so necessarily undermines this goal. ${ }^{111}$ Consider the recent duo of judgments in yet another PRASA saga. ${ }^{112}$ Both the court a quo and the appeal court found the relevant tenderer to be guilty of fronting in breach of the Empowerment Act, which fronting followed the standard formula of B-BBEE points in exchange for money:

"It is clear that Swifambo under the agreement with Vossloh was merely a token participant that received monetary compensation in exchange for the use of its B-BBEE rating. The B-BBEE points were the only aspect that Vossloh could not satisfy. Vossloh could not bid on its own. Instead it concluded an agreement with Swifambo in which its B-BBEE points were exchanged for money. Vossloh maintains complete control over the operations of the business and Swifambo's role is constrained to minor administrative activities. There is no substantive empowerment evident under the agreement between Vossloh and Swifambo. There is no transfer of skills during the agreement or after." 113

Considering matters of both principle and pragmatism, it is foreseeable that where a mere shot at consideration at pre-qualification level requires a stipulated minimum BBBEE status level, ${ }^{114}$ tenderers may unfortunately be all the more inclined to resort to such "tokenism" and thereby defeat real substantive equality gains for the sector. As

\footnotetext{
107 AllPay Merits para 51.

${ }^{108}$ A fronting practice is defined in the Broad-Based Black Economic Empowerment Act 53 of 2003 as "a transaction, arrangement or other act or conduct that undermines the achievement of the objectives of the Act. Section 1(c) refers to the 'conclusion of a legal relationship with a black person for the purpose of that enterprise achieving a certain level of broad-based black economic empowerment compliance without granting that black person the economic benefits that would reasonably be expected to be associated with the status or position held by that black person".

109 The Constitutional Court in Viking Pony Africa Pumps (Pty) Ltd t/a Tricom Africa v Hidro-Tech Systems (Pty) Ltd 2011 (1) SA 327 (CC) made reference to these synonyms at para 12, fn 11: "[a]lso known as 'window dressing' or "tokenism", and endorsed Bolton 2007: 293-4 where she describes fronting as "the practice of black people being signed up as fictitious shareholders in essentially 'white' companies."

${ }^{110}$ AllPay Merits para 55.

${ }^{111}$ See the cases of Eskom Holdings (n 43) and Aero-Duct Moya CC v Minister of Public Works (936/2019) [2019] ZAECPEHC 32 as recent (and disconcerting) illustrations of the malady that is fronting in the procurement space. 112 Passenger Rail Agency of South Africa v Swifambo Rail Agency (Pty) Ltd 2017 (6) SA 223 (GJ) (3 July 2017) ("PRASA HC") and Swifambo Rail Leasing (Pty) Limited v Passenger Rail Agency of South Africa (1030/2017) [2018] ZASCA 167 (30 November 2018) ("PRASA SCA").

113 PRASA HC para 95 (emphasis added) and PRASA SCA paras 25-30.

${ }^{114}$ As contemplated under subregulation 4(1)(a) of the 2017 Procurement Regulations.
} 
the court noted in Esorfranki Pipelines, fronting is a "fraud on those who are meant to be the beneficiaries of legislative measures put in place to enhance the objective of economic empowerment." ${ }^{115}$ A related pragmatic concern is that when it comes to targeted subcontracting, it may be practically difficult for organs of state to verify whether the subcontractors are indeed owned by the listed designated persons particularly where they are not required to register on the Central Supplier Database or provide proof of ownership. These practical difficulties may increase the likelihood of fronting and make its detection more challenging.

\section{The 2017 Regulations' emphasis on pre-qualification criteria is likely to spiral tender litigation for non-compliance with tender conditions}

The focus that the 2017 Regulations place on the use of pre-qualification criteria will not only reduce the number of players who can legitimately compete for public tenders, but may in addition increase litigation for purported want of compliance with tender conditions. This will in turn exacerbate the strain our courts are under in this field and further stultify the implementation of important government programmes. As noted above, a public procurement process is a quintessential form of administrative action and thus very often ripe for review on the array of grounds contained in the PAJA. ${ }^{116}$ Layered on top of this general framework is the niche regulatory procurement regime, and so potential complexities abound.

Section 1(i) of the Procurement Act defines an "acceptable tender" as one which "in all respects, complies with the specifications and conditions as set out in the tender document", ${ }^{117}$ such that a failure on the part of a bidder to so comply will (likely ${ }^{118}$ ) render the bid non-responsive and hence it will not be able to proceed to point allocation stage. Subregulation 4(2) of the 2017 Regulations affirms this by stating that, "[a] tender that fails to meet any pre-qualifying criteria stipulated in the tender documents is an unacceptable tender". ${ }^{119}$ But what is (un/)acceptable is seemingly not always a simple matter to determine. A cursory reflection of our law reports in this field

\footnotetext{
${ }^{115}$ Esorfranki Pipelines (Pty) Ltd and Another v Mopani District Municipality 2 All SA 493 (SCA) para 26.

${ }^{116}$ See section 6 of the PAJA on the various "grounds of review". Note that today these grounds are in large part replicated under the principle of legality, albeit in a diluted form in certain respects. See Kohn 2013: 810 and Hoexter 2011: 55.

117 Section 1(i) of the Procurement Act.

118 Depending on the application of the AllPay test and discussed below.

${ }^{119}$ Subregulation 4(2) of the 2017 Procurement Regulations.
} 
is palpably illustrative of a readiness on the part of disappointed bidders (and organs of state) to employ recourse to judicial review of tender processes on the basis of noncompliance with tender conditions. Prior to the seminal duo of AIIPay Judgments, ${ }^{120}$ the courts oscillated between strict insistence on formal compliance ${ }^{121}$ and adopting a more flexible substantive approach. ${ }^{122}$ I turn now to canvass briefly this jurisprudential trajectory.

421 Case law snapshot: ${ }^{123}$ strict compliance or a purposive, context-sensitive approach?

The pre-AllPay locus classicus on flexible, purposive interpretation of non-compliance with tender conditions is the seminal 2008 Supreme Court of Appeal decision in Millennium Waste. ${ }^{124}$ This case concerned a tender for the provision of services for the removal, treatment and disposal of medical waste materials (including hazardous items and substances such as hypodermic needles and anatomical waste respectively) in hospitals in Limpopo. The appellant's tender was disqualified as it failed to sign the declaration of interest form; a failure that was "occasioned by an oversight". ${ }^{125}$ The consortium was the successful bidder as it "was the only tenderer that complied fully with the relevant legislation and had submitted a clear proposal". ${ }^{126}$ This outcome ensued despite the technical evaluation committee's report having revealed the consortium's non-compliance with the technical requirements for the treatment of the waste materials and "sharps". ${ }^{127}$ Furthermore, the appellant had tendered to provide the service at a cost of R444 244,43 per month, compared with the consortium's R3 642 257,28 per month. The court held that,

"our law permits condonation of non-compliance with peremptory requirements in cases where condonation is not incompatible with the public interest and if such condonation is granted by the body in whose benefit the provision was enacted."

\footnotetext{
${ }^{120}$ AllPay Merits \& Remedy.

${ }^{121}$ Epitomised in the case of Dr JS Moroka Municipality v Betram (Pty) Limited [2014] 1 All SA 545 (SCA).

122 The case of Millennium Waste is salient here.

${ }^{123}$ See further Volmink 2014: 41 for a comprehensive overview of pre-2015 case law on this issue.

${ }^{124}$ Millennium Waste.

125 Para 19.

126 Para 9.

127 Para 10.
} 
Applying this principle to the facts, Jaftha JA noted that, "condonation of the appellant's failure to sign would have served the public interest as it would have facilitated competition among the tenderers" and so by condoning the failure, the tender committee would in fact have "promoted the values of fairness and competitiveness". ${ }^{128}$ This value-laden purposive mode of interpretation, done through the prism of section 217, permeates the court's reasoning throughout the judgment (on substance and remedy).

The court held that the notion of an "acceptable tender" as defined in the Procurement Act must strive "for an interpretation which promotes 'the spirit, purport and objects of the Bill of Rights'...[and] 'be construed against the background of the system envisaged by section 217(1)"'. ${ }^{129}$ In light of this, the court did not give "acceptable tender" its "wide literal meaning" and emphasised that "it certainly cannot mean that a tender must comply with conditions which are immaterial, unreasonable or unconstitutional". ${ }^{130}$ With materiality as the touchstone, the court considered the defect in light of the purpose of the declaration of interest form in relation to the tender process. Jaftha JA concluded that, "I am unable to appreciate how the signing of the form would have safeguarded against corruption. It seems to me that what is of paramount importance is the nature of the information furnished and not the signature" 131 and so, on the merits, substance had to trump form. ${ }^{132}$

This approach was followed in VDZ Construction, ${ }^{133}$ in which non-compliance with the tender condition that bids include original municipal billing clearance certificates was condoned. In this case, the municipality had excluded the applicant's tender for nonresponsiveness as it had (inadvertently) submitted a clearance certificate that included an original first page but a copy of the second page. The court placed substance over form and held that the municipality should have condoned this error in order to serve the public interest; in particular the need to increase competition for the public contract. ${ }^{134}$ This finding was bolstered by an appreciation of the purpose of the

\footnotetext{
128 Para 17.

129 Para 18.

130 Para 19.

131 Para 20.

${ }^{132}$ See further on the question of remedy from para 22, for the court's pragmatic and principled approach to the justice and equity enquiry within the meaning of section 172(1)(b) of the Constitution.

${ }^{133}$ VDZ Construction (Pty) Ltd v Makana Municipality [2011] ZAECGHC 64 (3 November 2011).

${ }^{134}$ Para 13.
} 
underlying tender condition, which the court held could similarly be achieved through submission of a copy of the certificate, for it did not detract from the municipality's aim of contracting solely with compliant suppliers.

In Sanyathi Civil Engineering \& Construction ${ }^{135}$ non-compliance with the condition in issue could not be condoned; but rightly so given its distinguishable nature as a technical substantive requirement. Here, the tender called for adjustable price bids, but the winning bidder tendered on the basis that, "[a] fixed firm price is offered. No escalation applicable." 136 The court held that this deviation was a "material technical divergence" 137 in that it resulted in a bid substantially different from what the tender conditions required, and which should therefore have been found non-responsive. The court concluded that,

"this case typifies how not to conduct procurement. The illegality and consequent procedural and substantive irregularities are precisely of the sort that the prescriptive constitutional and statutory framework seeks to prohibit. Even if Sanyathi and Group Five were not the best tenders on criteria other than price, i.e. the gate-keeping criteria, which might disqualify them again if they tender afresh, all the tenderers, the administration and the community deserve a fair procedure. A fair procedure is not only one that ensures transparency and competitiveness but also one that is free of the slightest whiff of corruption."

Two years later in the notoriously formalistic judgment of Dr JS Moroka Municipality, ${ }^{138}$ the Supreme Court of Appeal did a volte-face and overruled its approach to condonation of non-compliance with tender conditions as elucidated in Millennium Waste:

"insofar as the judgment in Millennium Waste Management may be construed as accepting that a failure to comply with the peremptory requirement of a tender may be condoned by a municipal functionary who is of the view that it

\footnotetext{
135 Sanyathi Civil Engineering \& Construction (Pty) Ltd and Another v eThekwini Municipality, Group Five Construction (Pty) Ltd v eThekwini Municipality (KZP) [2012] 1 All SA 200 (KZP) (24 October 2011).

136 Para 77.

137 Para 97.

${ }^{138}$ Dr JS Moroka Municipality v Betram (Pty) Limited [2014] 1 All SA 545 (SCA).
} 
would be in the public interest for such tender to be accepted, it should be regarded as incorrect." 139

JS Moroka concerned a "minimum qualifying requirement" to submit original tax clearance certificates. The respondent's bid was rejected on the basis that it submitted a copy in breach of this mandatory condition. It argued for condonation given that, notwithstanding this failure of form, its bid should have been accepted as it was R2 million less than that of the winning tenderer. Leach JA adopted a strict approach and rejected this argument. This finding was informed by the fact that the tender condition stemmed from the statutory "requirement that tenders should only be awarded to persons whose tax affairs have been declared by SARS to be in order". ${ }^{140}$

\section{AllPay clarifies the "proper legal approach"}

On the very same day that judgment was delivered in Dr JS Moroka, the Constitutional Court handed down the benchmark AlIPay Merits ${ }^{141}$ judgment, and with it came a move away from strict adherence to rigid formalities. In this case, our highest court set out the "proper legal approach to the existence and legal effect of proven irregularities"'142 and in doing so strongly endorsed a more flexible context-sensitive methodology that has, at its heart, an assessment of the materiality of the alleged non-compliance as

\footnotetext{
139 Para 18.

140 Para 11. Note that the strict approach in Dr JS Moroka has been applied in subsequent cases. For example, in Intsimbi Industrial Manufacturing CC v Municipality Manager of the Nelson Mandela Metropolitan Municipality [2015] ZAECPEHC 64, the court held that a bid submitted by a joint venture that was not registered on the contracting authority's supplier database was non-responsive given the peremptory formulation of the tender condition and underlying purpose of ensuring the contracting authority do business solely with suitable entities (i.e. those whose tax affairs are in order). In light of this, non-compliance was material and could not be condoned. (See para 43).

Similarly (and notwithstanding the judgment in AllPay), the High Court adopted a retrogressive approach to assessing non-compliance with tender conditions in Afriline Civils (Pty) Ltd v Minister of Rural Development And Land Reform; In re: Asla Construction (Pty) Ltd v Head of the Department of Rural Development and Reform [2016] 3 All SA 686 (WCC). In this case the bids of the respective applicants had been declared non-responsive for failure to submit tax clearance certificates for one of their subcontractors. Both bidders had explained in their bid documents that they were unable to do so as the subcontractor was a division of a larger entity whose tax certificate had indeed been submitted. The court ruled that, in light of the peremptory wording of this qualification criterion and the need to ensure a fair and transparent process, the authority was correct to declare the bids non-responsive. (para 17). Quinot has criticised this finding for being "overly formalistic", noting that "[o]ne wonders whether this extremely formal approach to transparency does not undermine the principle of competitiveness...The exclusion of these two bidders from the process had a significant adverse impact on the competition for the tender, but had very little beneficial impact on transparency given that the original tax certificate was before the relevant committees in any case and noted as such." (See Quinot 2016: 2.5.

${ }^{141}$ AllPay Merits.

142 Para 6(b).
} 
informed by the purpose of the condition or requirement. In my view, this is indeed correct in light of the general approach to constitutional adjudication; i.e. transformative, purposive interpretation that places substance over form and best gives effect to our constitutional values ${ }^{143}$ without losing sight of the legislative aim in question. All law and conduct must be constitutionally compliant, and in the procurement context, the animating section 217 constitutional blueprint necessarily calls for a sensitive, purposive, contextual balancing of several key principles in a manner that eschews formalism. Of course, the flipside of this coin is increased uncertainty of outcome for litigants and thus more of the chance-taking-litigating ${ }^{144}$ we increasingly see in this field; a trend likely to worsen since the 2017 Regulations came into effect. The AIIPay approach must therefore be properly appreciated and applied. The court formulated the methodology as follows -

"The proper approach is to establish, factually, whether an irregularity occurred. Then the irregularity must be legally evaluated to determine whether it amounts to a ground of review under PAJA. This legal evaluation must, where appropriate, take into account the materiality of any deviance from legal requirements, by linking the question of compliance to the purpose of the provision, before concluding that a review ground under PAJA has been established." 145

Froneman J confirmed that the "strict mechanical approach" to assessing the materiality of compliance with legal requirements (by drawing formal distinctions between "mandatory" and "directory" provisions) has been discarded. ${ }^{146}$ Instead, "the materiality of irregularities is determined by assessing whether the purposes the tender requirements serve have been substantively achieved." ${ }^{147}$ Of course, this test does not detract from the fact that, "[c]ompliance with the requirements for a valid tender process, issued in accordance with the constitutional and legislative procurement framework, is...legally required." 148 To summarise, the "proper legal

\footnotetext{
143 See for example, Langa 2006: 353 and Moseneke 2002: 315.

${ }^{144}$ See Moseme Road Construction CC v King Civil Engineering Contractors (Pty) Ltd 2010 (4) SA 359 (SCA) para

1 , "[t]endering has become a risky business".

${ }^{145}$ AllPay Merits para 28.

146 Para 30.

147 Para 58.

148 AllPay Merits para 40. The emphasised caveat is noteworthy for it highlights that tender document requirements will only be binding if they are congruent with the empowering legal framework.
} 
approach" to assessing alleged non-compliance with tender requirements is a kind of "but for test" that can explained as follows: ${ }^{149}$

- It requires a determination of what the purpose of the tender requirement (or condition) actually is, i.e. what aim is sought to be achieved or, put differently, what nuisance is sought to be addressed by it?

- This in turn necessitates a contextual interpretation of the provision in light of the actual tender document and regulatory framework read as a whole.

- Once this purpose is established, the materiality of an alleged deviation can be ascertained, essentially by asking whether but for that deviation, the purpose would (or would not) have been achieved.

- And where the so-called "deviation" is not material in the sense that the purpose of the requirement is, or will still be, attained despite the non-compliance, the tender will be rendered responsive and hence lawful in this respect.

More recent case law ${ }^{150}$ reveals, on balance, a proper appreciation of the AllPay test. For example, Abet Inspection Engineering, ${ }^{151}$ concerned a challenge to the decision of PetroSA to accept Vumela's tender notwithstanding non-compliance with a formal requirement pertaining to a SANAS accreditation certificate. The winning bidder, while having duly applied for the relevant certificates to be issued in its own name, had not yet received them at the time the bid was closed and so had to rely on the certificates issued in the name of the previous owner. The appeal court per Binns-Ward $\mathrm{J}$ (Allie and Matame JJ concurring) correctly applied the AllPay approach and held that that PetroSA's decision to accept the tender as compliant, despite the inconsequential matter of form, was valid. The court noted that,

"It is clear that in its treatment of 'materiality' the Constitutional Court [in AlIPay] endorsed the principle that substance should prevail over form. Thus, if the irregularity or apparent deviation from the legal requirements has not

\footnotetext{
${ }^{149}$ Note that this is my own unpacking of the methodology based on my reading of the judgments.

150 See also the case of Mobile Telephone Networks (Pty) Ltd $v$ Transnet Soc Ltd [2018] ZAGPJHC 454 para 13 where the court applies the AllPay evaluation, albeit with the result that non-compliance was found to be material and could not be condoned.

${ }^{151}$ Abet Inspection.
} 
substantively detracted from or undermined the purpose or object of the relevant governing provision, a court might conclude upon contextual evaluation that it does not make out a cogent basis for judicial review". ${ }^{152}$

In this case, the nature of the deviation was "so entirely formalistic" that to hold it amounted to a review ground "would be to unjustifiably elevate form above substance" given that the irregularity ("if there was one") was "incontestably immaterial". ${ }^{153}$ Moreover, the court found that had the evaluation team disqualified the tender as nonresponsive in the circumstances, this would have frustrated rather than promoted the objects of section 217 ; most notably competitiveness and cost-effectiveness. ${ }^{154}$

What conclusions - if speculative - might we draw from the case law considered in light of the 2017 Regulations' allowance of pre-qualification criteria on the basis of preference? Tendering has always been a messy business: there is layer upon layer of regulatory red-tape which is often unclear and so inconsistently applied, and while government tenders are generally rather lucrative, even once awarded they are not necessarily a sure thing as pacta sunt servanda may become meaningless where legality is concerned and a court sets a tender aside for non-compliance with its conditions. This results in a chilling-effect in that sensible businesses are becoming increasingly reticent to bid; a phenomenon which may be aggravated by Gijima pursuant to which state self-review must now take place on the basis of legality, rather than via the PAJA with its stricter time bar provisions, which in turn means that realistically a successful bidder can no longer simply wait out the PAJA six month period (for the institution of review proceedings ${ }^{155}$ ) to feel relatively secure in the investment. ${ }^{156}$

\footnotetext{
152 Para 7. Emphasis added.

153 Para 24.

154 Para 24.

155 Although, as noted above at 1, this time-period under the PAJA may be condoned in exceptional circumstances.

${ }^{156}$ See the brief discussion on Gijima at section 1 above and the commentary cited there. Note, however, that in some instances it may be harder for the state party seeking to review its own decision to have it set aside insofar as while the substantive review grounds under legality are burgeoning to mirror those under the PAJA (see Kohn 2013: 810), the grounds of procedural fairness and reasonableness arguably still fall (at least marginally) short of their PAJA counter-parts.
} 
Add to this the 2017 Regulations' green-light to organs of state to restrict bids to those that pre-qualify on the basis of preference and there will be little to no incentive for non-qualifying (but otherwise eligible) players to enter the game, resultantly reduced competition, and in turn (likely) diminished cost-effectiveness given that shrinking the pool of bidders and hence the availability of pricing information, may lead to less costeffective outcomes. There is also an argument to be made that reducing the pool of bidders may result in increased corruption in the form of bid rigging. ${ }^{157}$ Furthermore, with so much now hinging on B-BBEE, pre-qualification of tenders may exacerbate fronting practices. On the issue of spiralling tender litigation, the AllPay methodology provides some solace in the form of a sensible approach to assessing (non-) compliance with tender conditions, but it is relatively open-textured and contingent on the judicial assessment of "materiality" and "purpose". So, where does this leave us? With a pressing need to go back to first principles lest the section 217 procurement essentialia of competitiveness and cost-effectiveness become redundant. In what follows, I make further concluding remarks and propose some solutions.

\section{Conclusion: Reflections on the way forward}

Government has itself recently acknowledged the many flaws in our regulatory procurement framework with its myriad of laws and policies and their imprecisions, anomalies, apparent contradictions and the like. ${ }^{158}$ The Procurement Act may be outdated and may not pay sufficient heed to empowerment - it may not go quite far enough - however, its redeeming feature is perhaps ironically just that: it does not attempt to do too much; it remains true to the spirit and purport of its underpinning section 217 constitutional imprimatur, and in so doing, it establishes a relatively clear and balanced methodology for preferential public procurement. The 2017 Regulations detract from, and indeed undermine, this methodology in a way that is offensive to legality and rationality minimally conceived. They upset the balance established under the Act in a manner that is irrational and ultra vires both the PPPFA and its underpinning constitutional procurement precepts collectively considered. The

\footnotetext{
${ }^{157}$ See OECD Guidelines for Fighting Bid Rigging in Public Procurement. Available at https://www.oecd.org/competition/cartels/42851044.pdf at 2: "[b]id rigging is more likely to occur when a small number of companies supply the good or service. The fewer the number of sellers, the easier it is for them to reach an agreement on how to rig bids" (accessed 28 January 2020).

${ }^{158}$ See generally the 2015 SCM Review.
} 
irrationality of the Regulations is all the more unpalatable when we consider that they may (if speculatively and inadvertently) have the consequence of vitiating meaningful economic empowerment by spurring on unlawful fronting practices.

Furthermore, with so much riding on pre-qualification conditions, judicial reviews of procurement processes will increasingly occupy our courts' attention; further diminish our "administrative law dream" of a coherent and responsive "integrated" system; 159 and lead to worsened stalemate in government service and infrastructure delivery. The 2017 Regulations, considered against the backdrop of the empowering Act and section 217 of the Constitution, represent an attempt at fitting a round peg in a square hole. The Procurement Act simply does not accommodate certain key changes introduced under the Regulations. One can but hope that the anticipated Public Procurement Bill rectifies this anomalous situation, though with its ambitious procurement agenda, ${ }^{160}$ government may continue to attempt to bite off more than it can chew, constitutionally speaking.

Government is therefore urged to go back to the basics and develop a future-fit Procurement Framework that does justice to all the constitutional procurement prescripts and hence does not lose sight of the significance of price in the equation. As Occam's Razor holds, the best answer is typically the simplest one and so perhaps the most legitimate and sustainable way of furthering equity, without compromising the other prescripts, is to alter the price-to-preference ratios under the empowering Act (to say, an 80/20 and 70/30 split respectively ${ }^{161}$ ). This would tip the scales in favour of preference in a lawful and rational manner that does not serve as a bar to meaningful consideration of price. Such a clear and elegant legislative solution would also alleviate the pressure on our courts in this vexed context where separation-of-powers neuroses (rightly) manifest. After all, as our Constitutional Court put it in Pharmaceutical Manufacturers,

"Administrative law, which forms the core of public law, occupies a special place in our jurisprudence. It is an incident of the separation of powers under which courts regulate and control the exercise of public power by the other branches

\footnotetext{
159 Hoexter 2000: 485.

${ }^{160}$ As articulated in, for example, the 2015 SCM Review.

${ }^{161}$ I must credit Raisa Cachalia here for her invaluable commentary on this point.
} 
of government. It is built on constitutional principles which define the authority of each branch of government, their inter-relationship and the boundaries between them." 162

These boundaries must be respected; especially in the procurement space where policy issues abound and the spending of public money is inevitably a concern. Flowing from this point, special provision for tender courts ${ }^{163}$ would be a welcome step in enhancing access to justice here and respect for the separation-of-powers tenets. ${ }^{164}$ The addition of a fast-track, specialised court structure in this arena would furthermore improve accountability, responsiveness and openness in our transformative democratic system committed to, amongst others, the rule of law, human rights realisation and good governance. The stakes are high: government must after all do right and it must do so properly. ${ }^{165}$ The time for this is now.

\section{Bibliography}

\section{Books}

Bolton, P. 2007. The Law of Government Procurement in South Africa. Durban: LexisNexis

Hoexter, C. 2012. Administrative Law in South Africa. Cape Town: Juta Williams-Elegbe, S. \& Quinot, G. 2018. Public Procurement Regulation for $21^{\text {st }}$ Century Africa. Cape Town: Juta

\footnotetext{
162 Pharmaceutical Manufacturers para 45.

${ }^{163}$ Akin to the electoral court system provided for under the Electoral Act 73 of 1998 . See section 96, "Jurisdiction and powers of Electoral Court -

(1) The Electoral Court has final jurisdiction in respect of all electoral disputes and complaints about infringements of the Code, and no decision or order of the Electoral Court is subject to appeal or review....".

I am grateful to O'Regan J for an illuminating discussion on this topic in 2018.

164 Namely the matters of democratic principle and institutional competence. See Kohn 2013: 810 and the authorities cited thereat.

${ }^{165}$ Kirland para 82.
} 


\section{Chapters in edited collections}

Hoexter, C. 2011. The rule of law and the principle of legality in administrative law today. In Carnelley, M. \& Hoctor, S. (Eds.). Law, Order and Liberty: Essays in Honour of Tony Mathews. Cape Town: Juta

Davis, D. 1993. Administrative Justice in a democratic South Africa. In T.W. Bennett \& H. Corder. (Eds.). Administrative Law Reform. Cape Town: Juta

Penfold, G. \& Reyburn, P. 2008. Public Procurement. In Woolman, S. \& Bishop, M. (Eds.). Constitutional Law of South Africa. Cape Town: Juta

\section{Journal Articles}

Boonzaier, L. 2018. A decision to undo. South African Law Journal 135(4): 642

Cachalia, R. 2015. Clarifying the exceptional circumstances test in Trencon: an opportunity missed. Constitutional Court Review 7:115

De Beer, M. 2018. A new role for the principle of legality in administrative law: State Information Technology Agency Soc Ltd v Gijima Holdings (Pty) Lt.' South African Law Journal 135(4): 613

Hoexter, C. 2000. The Future of Judicial Review in South African Administrative Law. South African Law Journal 117: 484

Klare, K. 1998. Legal Culture and Transformative Constitutionalism. South African Journal on Human Rights 14(1): 146

Kohn, L. 2013. The burgeoning constitutional requirement of rationality \& the separation of powers: Has rationality review gone too far? South African Law Journal 130: 810

Kohn, L. \& Cachalia, R. 2017. Restitutionary Measures properly understood \& the extension of the Quota Ban - Locating SARIPA in the s 9(2) Van Heerden Framework. Acta Juridica 146

Kohn, L. 2016. The Bashir judgment raises the red flag for the Rule of Law and the Judiciary. South African Law Journal 133(2): 246 
Kohn, L. 2015. The Test for 'Exceptional Circumstances' where an Order of Substitution is sought: An Analysis of the Constitutional Court judgment in Trencon against the backdrop of the Separation of Powers. Constitutional Court Review 7: 91 Langa, P. 2006. Transformative Constitutionalism. Stellenbosch Law Review 17: 351 Moseneke, D. 2002. The Fourth Brain Fischer Memorial Lecture: Transformative Adjudication. South African Journal on Human Rights 18: 309

Quinot, G. 2014. The role of quality in the adjudication of public tenders. Potchefstroom Electronic Law Journal 1112

Quinot, G. 2016. Strict compliance with tender conditions and tax clearance certificates. JQR Public Procurement.

Quinot, G. 2017. The New Preferential Procurement Regulations. JQR Public Procurement.

Volmink, P 2014. Legal consequences of non-compliance with bid requirements African Public Procurement Law Journal 1:41.

\section{Cases}

ABET Inspection Engineering (Pty) Ltd v The Petroleum Oil and Gas Corporation of South Africa [2018] ZAWCHC 7

Aero-Duct Moya CC v Minister of Public Works (936/2019) [2019] ZAECPEHC 32

Afriline Civils (Pty) Ltd v Minister of Rural Development And Land Reform; In re: Asla Construction (Pty) Ltd v Head of the Department of Rural Development and Reform [2016] 3 All SA 686 (WCC)

AllPay Consolidated Investment Holdings (Pty) Ltd v Chief Executive Officer of the South African Social Security Agency (No. 1) 2014 (1) SA 604 (CC) AllPay Consolidated Investment Holdings (Pty) Ltd v Chief Executive Officer of the South African Social Security Agency (No. 2) 2014 (4) SA 179 (CC) 
Contour Technology (Pty) Limited v Chairperson of the Bid Adjudication Committee: Modimole Local Municipality [2017] ZAGPPHC 496

Democratic Alliance $v$ Public Protector; Council for the Advancement of the South African Constitution v Public Protector [2019] ZAGPPHC 132

Dr JS Moroka Municipality v Betram (Pty) Limited [2014] 1 All SA 545 (SCA)

Electronic Media Network Limited Others v e.tv (Pty) Limited 2017 (9) BCLR 1108 (CC)

Eskom Holdings SOC Limited v McKinsey and Company Africa (Pty) Ltd [2019] ZAGPPHC 185

Esorfranki Pipelines (Pty) Ltd and Another v Mopani District Municipality 2 All SA 493 (SCA)

Fedsure Life Assurance Ltd v Greater Johannesburg Transitional Metropolitan Council 1999 (1) SA 374

Glenister v President of the Republic of South Africa [2013] ZACC 20

Intsimbi Industrial Manufacturing CC v Municipality Manager of the Nelson Mandela Metropolitan Municipality [2015] ZAECPEHC 64

Joburg Market SOC Ltd v Aurecon South Africa (Pty) Limited [2017] ZAGPJHC 145 Logbro Properties CC v Bedderson NO [2003] 1 All SA 424 (SCA)

Masetlha v President of the Republic of South Africa 2008 (1) SA 566 (CC)

MEC for Health, Eastern Cape and Another v Kirland Investments (Pty) Ltd 2014 (3) SA 481 (CC)

Minister of Social Development v Phoenix Cash \& Carry Pmb CC [2007] 3 All SA 115 (SCA)

Mobile Telephone Networks (Pty) Ltd v Transnet Soc Ltd [2018] ZAGPJHC 454 
Moseme Road Construction CC v King Civil Engineering Contractors (Pty) Ltd 2010 (4) SA 359 (SCA)

Pharmaceutical Manufacturers Association of South Africa and Another: In re Ex Parte President of the Republic of South Africa 2000 (2) SA 674 (CC)

Passenger Rail Agency of South Africa v Swifambo Rail Agency (Pty) Ltd 2017 (6) SA 223 (GJ)

Sanyathi Civil Engineering \& Construction (Pty) Ltd and Another v eThekwini Municipality, Group Five Construction (Pty) Ltd v eThekwini Municipality (KZP) [2012] 1 All SA 200 (KZP)

State Information Technology Agency SOC Limited v Gijima Holdings (Pty) Limited 2018 (2) SA 23 (CC)

Steenkamp NO v Provincial Tender Board of the Eastern Cape 2007 (3) SA 121 (CC)

Swifambo Rail Leasing (Pty) Limited v Passenger Rail Agency of South Africa (1030/2017) [2018] ZASCA 167

Trencon Construction (Pty) Limited v Industrial Development Corporation of South Africa Limited 2015 (5) SA 245 (CC)

VDZ Construction (Pty) Ltd v Makana Municipality [2011] ZAECGHC 64

Viking Pony Africa Pumps (Pty) Ltd t/a Tricom Africa v Hidro-Tech Systems (Pty) Ltd 2011 (1) SA 327 (CC)

\section{Legislation}

Constitution of the Republic of South Africa, 1996

Broad-based Black Economic Empowerment Act 53 of 2003

Electoral Act 73 of 1998.

Local Government: Municipal Systems Act 32 of 2000 
Local Government: Municipal Finance Management Act 56 of 2003

The Promotion of Access to Information Act 2 of 2000

The Promotion of Administrative Justice Act 3 of 2000

The Public Finance Management Act 1 of 1999

The Preferential Procurement Policy Framework Act 5 of 2000

The Preferential Procurement Regulations, 2011, published in Government Notice No. R502 of 8 June 2011

The Preferential Procurement Regulations, 2017, published in Government Notice No. R32 of 20 January 2017

\section{Internet Sources}

Kohn, L 'State procurement: The changing face of Public Procurement in SA' (2018) http://www.caveatlegal.com/state-procurement-the-changing-face-of-publicprocurement-in-

sa/?fbclid=IwAR3mr4W3b3nRnQG 0hRGrjd2ADj7GPdo99fCSxJQd2hrGDU ooQEh oFmlzg (Accessed 24-02-2020).

Van Wyngaardt, M 'Public Procurement aligned to more stringent regulations as Bill goes to Cabinet' (2018) https://www.polity.org.za/article/public-procurement-alignedto-more-stringent-regulations-as-bill-goes-to-cabinet-2018-02-21 (Accessed 24-022020).

World Bank The World Bank Group and Public Procurement: An Independent Evaluation International Bank for Reconstruction and development / The World Bank (2014) https://openknowledge.worldbank.org/handle/10986/16673 (Accessed 24-022020).

The National Treasury Public Sector Supply Chain Management Review (2015) http://www.treasury.gov.za/publications/other/SCMR\%20REPORT\%202015.pdf (Accessed 24-02-2020). 
The National Treasury's 'Frequently asked Questions Brochure' on the 2017 Procurement Regulations

http://www.nwpg.gov.za/treasury/procurement2/documents/Frequently\%20asked\%2 0Questions\%20and\%20Generic\%20\%20Answers\%20-

\%20Preferential\%20Procurement $\% 20$ Regulations $\% 202017 \% 20$ -

\%20Version\%201\%201.pdf (Accessed 24-02-2020).

Gauteng Provincial Government: Supply Chain Management Policy Model

http://www.treasury.gpg.gov.za/Documents/Supplier\%20Chain\%20Management $\% 20$ Policy\%20Model.pdf (Accessed 24-02-2020).

National Treasury CFO Forum Induction of 2 March 2017: Preferential Procurement Regulations, 2017.

https://oag.treasury.gov.za/Event\%20Documentation/20170302\%20CFO\%20Forum \%20-\%20AFS\%20Training/20170302\%20-

\%20Presentation $\% 20$ on $\% 20$ the $\% 20$ revised $\% 20$ Preferential\%20Regulations $\% 20201$ 7-\%20National\%20Treasury\%20CFO\%20Forum.ppt (Accessed 24-02-2020).

OECD Guidelines for Fighting Bid Rigging in Public Procurement. Available at https://www.oecd.org/competition/cartels/42851044.pdf (Accessed 24-02-2020). 